\title{
Teaching Games for Understanding and Cooperative Learning: Can Their Hybridization Increase Motivational Climate among Physical Education Students?
}

Óscar Chiva-Bartoll', Celina Salvador-García', and Pedro Jesús Ruiz-Montero²

'Jaume I University, Department of Education

${ }^{2}$ University of Granada, Physical Education and Sport Department

\section{Abstract}

The present study examines the evolution of Motivational Climate among Physical Education students through the hybridization of Cooperative Learning and the Teaching Games for Understanding model in a handball didactic unit. A sample of 96 students, whose average age was fifteen, were divided into an experimental group of 31 students and a control group of 65 students. The Motivational Climate evolution promoted by the hybrid model (experimental group) was compared with the results obtained through a traditional learning approach (control group). The results show differences in the Task-involvement scale, (Effort/ Improvement and Important Role subscales), and in the Ego-involvement scale (Unequal Recognition subscale). In conclusion, in accordance with the results obtained by similar research on other sports, significant differences were found between the two scales with regard to the perceived motivational climate.

Key words: cooperative learning; motivational climate; physical education; secondary school; teaching methodology.

\section{Introduction}

The Physical Education (PE) curriculum has been reformed in most countries across the world in the last decades. The goal of the new PE curricula is to develop 
physically educated individuals who possess the knowledge, skills, and confidence to enjoy a lifetime of healthful physical activity, instead of solely educating the physical body (Wang \& Ha, 2013). In this vein, a number of constructivist-based pedagogical models have attracted increasing attention from teachers and scholars, such as the Teaching Games for Understanding (TGfU) model (Bunker \& Thorpe, 1982). The TGfU model is a learner-centred approach to PE in which teachers are encouraged to design modified games to develop the learner's understanding of tactical concepts (Griffin, Brooker, \& Patton, 2006; Renshaw, Araújo, Button, Chow, Davids, \& Brendan, 2016). Particularly, the TGfU model shows that cognitive functions have great relevance basically due to decision-making (Balakrishnan, Shabeshan, \& Salleh, 2011; Johnson \& Raab, 2003; Raab \& Johnson, 2007; Raab \& Laborde, 2011; Wagner, Finkenzeller, Würtn, \& von Duvillard, 2014) and attention processes required by the game (Memmert, Simons, \& Grimme, 2009; Swinney, 2004), using constructivist learning principles (Griffin \& Patton, 2005). Table 1 shows the main elements required when learning sports through the TGfU model.

Table 1

Student benchmarks of the TGfU model

Student Benchmarks

Students are given time to think about open-ended questions

Students are engaged in making tactical decisions

Students make progress in tactical knowledge as they move from the initial game through technique/skill practice(s) to the final game

Students have learned tactical awareness, decision-making, and skill application

Note. Adapted from Bunker \& Thorpe (1982); Metzler (2011); O'Leary (2015); Thorpe, Bunker, \& Almond (1984).

Moreover, cooperative learning is an educational methodology in which small groups of students, each with pupils of different ability levels, work together on a common task to maximize their own and each other's learning, sharing efforts and resources (Johnson, Johnson, \& Holubec, 1999). Furthermore, most of the curriculum for school Physical Education (PE) is spent on games (Werner, Thorpe, \& Bunker, 1996) which can be played in this approach. This methodology goes beyond mere group work because students aspire to not only learn a specific content, but also help their classmates achieve their own learning aims (Dyson, 2002). Similarly, this methodology is widely considered useful for encouraging a positive classroom atmosphere, increasing students' self-concept, enhancing the inclusion of students with disabilities, co-education, and motivation towards the subject matter (Velázquez, 2015).

According to Fernández-Río and Méndez-Giménez (2016), cooperative learning has been successfully used in the PE curriculum to develop a number of contents such as (among others) basic skills, gymnastic skills, physical condition and health, and expressive or outdoor activities. However, its implementation in the process of sports teaching and learning has been more complex and less free-flowing. When cooperative learning was linked to sports education, it usually meant the introduction 
of a range of strategies such as modifying activity rules, reducing or even removing competitiveness and increasing cooperativeness, and transforming sports to create new games or activities from a cooperative viewpoint. Cooperative learning structures were used by Gröben (2005) to teach handball on the Primary Education level with implications for transference and social improvement. Besides, self-perception and motor improvement do not suffer any damage, but there is an increase in the percentage of correct trials (Barrett, 2005).

Currently, there is a tendency towards the hybridization of pedagogical models to increase their impact since many of them complement each other (Fernández-Río \& Méndez-Giménez, 2016; González, Cecchini, Fernández-Rio, \& Méndez, 2008). In this vein, cooperative learning has already been combined with the TGfU model on several occasions to better address PE sports contents (Méndez-Giménez, 2010). The cooperative TGfU hybrid model of the present study aspires to profit from the former's need for a classification system of sports games based on the tactical requirements of each game. Furthermore, although the structures of the game remain similar, changes can be made to adapt it to the students' age and skills. In addition, exaggerations of the tactical issue to develop are added as well.

Furthermore, several studies show that PE students' motivation is a key factor for enhancing their physical exercise practice (Moreno, Cervelló, Huéscar, Belando, \& Rodríguez, 2013). In this sense, it is important to bear in mind the two main sociocognitive theories of motivation which can explain the types of behaviour that may appear in PE lessons: achievement goal theory and self-determination theory. Achievement goal theory (Ames, 1992) is considered to be one of the theoretical models which has contributed more critically to the understanding of cognitive, behavioural, and emotional patterns related to PE students' achievement. According to this theory, two contrasting achievement goal constructs have been differentiated and each one of them is linked to a contrasting pattern of motivational processes: ego-involved (performance-oriented) and task-involved (mastery-oriented) goals.

For its part, self-determination theory focuses on self-motivation, personality integration, social functioning, and the conditions that enable those positive processes. Students' motivation to perform an activity is determined by meeting these needs. In this sense, several types of motivation can be differentiated: intrinsic motivation, extrinsic motivation, and amotivation (Ryan \& Deci, 2007). González-Cutre, Sicilia, and Moreno (2011) manipulated the target areas over several motivational variables to analyse the effects of a task-involvement climate. Students in the intervention group reported improvements in their task climate perception, mastery approach orientation, mastery avoidance orientation, and intrinsic motivation.

The positive effect of cooperative learning on students' motivation has been demonstrated, although it is not specifically focused on motivational climate. Cooperative learning seems to be better than traditional learning not only with respect to motivation related to motor practice (Fernández-Río, 2009), but with regards to the 
achievement of social, motivational, and affective goals (Prieto \& Nistal, 2009). Thus, the hybrid model might be related to task-involvement motivation as well.

Similarly, based on the hybrid model principles, the following theoretical proposal may be established. Those contexts in which interpersonal competition, public evaluation, and normative feedback related to the development of the task are encouraged, tend to crystallise in the students' performance-oriented motivation. In contrast, contexts that emphasise the learning process, participation, individual mastery of the task, and problem resolution contribute to the adoption of masteryoriented success criteria (Peiró, 1999).

Whilst several studies have applied the hybrid model of learning to the study of sports such as athletics (Casey, Dyson, \& Campbell, 2009), tennis (Casey \& Dyson, 2009), basketball (Fernández-Río, 2009), or volleyball and football (Dyson, 2010), no studies have been found which investigate handball. The present paper focuses on this sport and as such represents a new contribution to this area of knowledge. The analysis of the hybrid model in handball is needed because it is one of the most widespread sports in worldwide school curricula (Kirk, Macdonald, \& O'Sullivan, 2006). The results obtained will let us compare and discuss the effects of the hybrid model applied to teaching and learning handball in comparison with other sports.

The main objective of the research is to examine whether the aforementioned theoretical relations between cooperative learning and the TGfU model, promote the development of a specific motivational climate, and whether these results differ from those obtained through a traditional approach to teaching sports in PE. The two hypotheses taken into account in the present research are: (1) variables related to the perceived motivational climate will improve after implementing the teaching unit, showing an increase in task-involvement and a decrease in ego-involvement for students following the hybrid model; and (2) variables related to the perceived motivational climate will differ when comparing the evolution of both groups of participants (hybrid model and traditional approach).

\section{Methods}

\section{Participants}

A sample of 96 students of the 4th level of a secondary school located in Valencia (Spain) participated in this study during the 2015/2016 academic year. The experimental group comprised 31 students (16 girls and 15 boys), while 65 students constituted the control group ( 34 girls and 31 boys). This sample distribution corresponds with the widespread use of intact groups in educational research (Mertens, 2010). We decided to include three groups of students in the study in an attempt to not disregard any of the students. Therefore, one of the groups was assigned the experimental group role, while the other two combined made up the control group.

Before participating in the study, each student and his or her family were informed of its purpose. Furthermore, written informed consent was obtained from all of them (students and their families). 


\section{Measures}

Students responded to a PE-adapted version of the PMCSQ-2 (Newton, Duda, \& Yin, 2000), which was translated into Spanish by González-Cutre, Sicilia, and Moreno (2008). The instrument contained 33 items divided into Task-involvement and Ego-involvement scales. The Task-involvement scale consisted of 17 items and the Ego-involvement scale included 16 items. The Task-involvement scale comprises the subscales Cooperative Learning (four items), Effort/Improvement (eight items), and Important Role (five items), whereas the Ego-involvement scale comprises the subscales of Punishment for Mistakes (six items), Unequal Recognition (seven items), and Intra-Team Member Rivalry (three items). Each item of the questionnaire was preceded by the stem "In PE lessons ...," and followed by a Likert scale ranging from 1 (strongly disagree) to 5 (strongly agree). Previous studies conducted in sport and other physical activities have supported the reliability and factorial validity of the PMCSQ-2 (Newton et al., 2000).

\section{Procedure}

A quasi-experimental design with a pre-test/post-test non-equivalent group design was used. Data were collected twice. The present study was initiated at the beginning of March and concluded at the end of April 2016 (eight weeks), performing a posttest. The experimental group developed a teaching unit based on the cooperativeTGfU hybrid model for learning sports, whereas the control group was taught another teaching unit based on the traditional approach to sports teaching. The interventional hybrid model had a $90 \%$ attendance rate during this period.

A handball teaching unit was applied through a cooperative-TGfU hybrid model of learning sports, based on the proposal by Fernández-Río (2006). The intervention was related to the performance-oriented discourses approach (Tinning, 1996) in PE, which, at the same time, is characteristic of a performance-oriented curriculum rationality (López, Monjas, \& Pérez, 2003; Tinning, 2006). Table 2 shows the configuration of the teaching unit.

The hybrid model consisted of contents related to handball (basic to intermediate level), always established according to the current legislation in the application context. The eight sessions included in this interventional program took place twice a week, through 55-60-minute daily sessions, and effective 45-minute physical activity sessions, in line with the requirements laid down by the ACSM (2014) and the models proposed by Müller, Gert-Stein, Konzag, and Konngaz (1996), and Antón (1990). Participants' physical fitness and performance of physical exercises were controlled by specialists. Finally, the use of the Spanish version of the PMCSQ-2 was slightly adapted to the PE lesson because of the singularity of this scholar subject. The term "coach" was changed into "teacher," "athlete" into "student," and "training" into "lesson."

To ensure (among other things) fidelity and responsibility of the investigation, the study followed the ethical considerations proposed by the American Psychological Association (APA, 2010). 
Table 2

Teaching unit design of the proposal for innovation

Teaching Unit: HANDBALL - Secondary School Education

\footnotetext{
Learning objectives

- To understand and apply the main principles related to the sport handball.

- To understand the relevance of cooperation and learn to cooperate in order to help the team win games and matches.

- To be responsible for their own learning process by assuming roles such as referee or coach.

- To be an active participant in one's and the learning process of one's classmates.

Contents

- Handball: team sport, cooperation-opposition, and invasion sport.

- Development of cooperative games in group, related to the basic skills of the handball player, to enhance entertainment and having fun.

- Handball rules in order to use them during the game.

- Understanding and explaining games, observing and assessing essential aspects for its development, and supervising compliance with the rules.

- Playing games that are increasingly more complex and progressively approach the standard sport.

- Analysing the strengths and weaknesses of the group, creating strategies, appreciating the results obtained and proposing improvements.

- Understanding their responsibility in the learning process, including self-evaluation, and coevaluation.

\section{Methodological aspects}

- Heterogeneous groups remain the same during the whole teaching unit related to both team games related to handball, and learning from the group perspective.

- Games are designed to facilitate posing questions that encourage students to think.

- Cooperative work structures are created by each group member assuming different roles. These roles change along the teaching unit.
}

\section{Variables}

The motivational climate was the dependent variable, composed of Task-involvement and Ego-involvement. Likewise, Task-involvement was subdivided into three different dimensions: Cooperative Learning, Effort/Improvement, and Important Role; Egotask was divided into three additional dimensions: Punishment for Mistakes, Unequal Recognition, and Intra-Team Member Rivalry. Therefore, 9 dependent variables were analysed in relation to 2 independent variables: teaching approach of the teaching unit (cooperative-TGfU hybrid model of learning and traditional approach) and the moment of measurement (before and after the implementation of the teaching unit).

\section{Statistical Analysis}

Normality of distribution was tested using skewness and kurtosis z-test of experimental and control groups. At this point, it is important to note that when kurtosis is clearly greater than 0 (approximately greater than 1 ), the $\mathrm{F}$ tends to be too small and we cannot reject the null hypothesis even though it is incorrect. The opposite is the case when the kurtosis is less than -1. In any case, none of these tests can fully substitute a visual examination of the data using a histogram. Taking into account the above-mentioned points, the results obtained in this study led to the use of non-parametric statistics. 
Social statistical methods were used to calculate the means and standard deviation (SD), and differences of the total sample, active and control group using KruskalWallis' one-way analysis of variance for age and gender. In order to establish the differences in motivational profile variables between the experimental and control group, the Mann-Whitney U test was used for two independent groups of participants. Data were analysed using the SPSS statistical program (SPSS for Windows 21.0, Inc., Chicago, Illinois, USA). For all analyses, significance was accepted at $\mathrm{P}<0.05$.

\section{Results}

Changes in the motivational climate were compared using the Spanish version of the PMCSQ-2. Table 3 provides an overview of the age and gender of the study sample by groups and in total.

Table 3

Age and gender of the study sample by groups and in total

\begin{tabular}{ccccc}
\hline & $\begin{array}{c}\text { Sample } \\
(\mathrm{N}=96) \\
\text { Mean (SD) }\end{array}$ & $\begin{array}{c}\text { Experimental group } \\
(\mathrm{N}=31) \\
\text { Mean }(\mathrm{SD})\end{array}$ & $\begin{array}{c}\text { Control group } \\
(\mathrm{N}=65) \\
\text { Mean }(\mathrm{SD})\end{array}$ & p-value $^{\text {a }}$ \\
\hline Age & $15(0.7)$ & $15(0.4)$ & $15(0.6)$ & .63 \\
Gender & $\begin{array}{c}\text { (girls/boys) } \\
\text { (girls/boys) }\end{array}$ & $\begin{array}{c}\text { (girls/boys) } \\
34 / 31\end{array}$ & .18 \\
\hline
\end{tabular}

Note. $\mathrm{SD}=$ Standard Deviation; ${ }^{\mathrm{a}}$ one-way Kruskal-Wallis for age and gender of the study sample.

Next, Table 4 shows descriptive values of the motivational achievement profiles: mean, standard deviation (SD), evolution of means from pre-test to post-test and p-value.

Table 4

Difference between study samples by groups in motivational achievement profiles

\begin{tabular}{|c|c|c|c|c|c|c|c|}
\hline \multirow[b]{2}{*}{ Motivational profiles } & \multicolumn{3}{|c|}{ Experimental group $(\mathrm{N}=31)$} & \multicolumn{4}{|c|}{ Control group $(\mathrm{N}=65)$} \\
\hline & $\begin{array}{c}\text { Pre-test } \\
\text { Mean } \\
\text { (SD) }\end{array}$ & $\begin{array}{l}\text { Post-test } \\
\text { Mean } \\
\text { (SD) }\end{array}$ & $\begin{array}{c}\text { Post-test/ } \\
\text { Pre-test } \\
\text { evolution } \\
\text { Mean (SD) }\end{array}$ & $\begin{array}{c}\text { Pre-test } \\
\text { Mean } \\
\text { (SD) }\end{array}$ & $\begin{array}{c}\text { Post-test } \\
\text { Mean } \\
\text { (SD) }\end{array}$ & $\begin{array}{l}\text { Post-test- } \\
\text { Pre-test } \\
\text { evolution } \\
\text { Mean (SD) }\end{array}$ & $\mathrm{p}$-value \\
\hline Motivational Climate & $2.9(0.4)$ & $2.8(0.4)$ & $-.12(.52)$ & $3.1(0.3)$ & $3.1(0.3)$ & $.10(.38)$ & .064 \\
\hline Task-involvement & $3.3(0.6)$ & $3.8(0.6)$ & $.54(.83)$ & $3.5(0.6)$ & $3.4(0.6)$ & $-.12(.86)$ & .003 \\
\hline Cooperative Learning & $3.2(0.8)$ & $3.7(0.6)$ & $.54(1.2)$ & $3.3(0.9)$ & $3.4(0.8)$ & $.17(1.2)$ & .171 \\
\hline Effort/Improvement & $3.5(0.7)$ & $3.9(0.6)$ & $.41(.95)$ & $3.8(0.6)$ & $3.6(0.6)$ & $-.17(.77)$ & .005 \\
\hline Important Role & $2.9(0.7)$ & $3.7(0.8)$ & $.76(1.1)$ & $3.2(0.8)$ & $3.1(0.8)$ & $.11(1.1)$ & .004 \\
\hline Ego-involvement & $2.6(0.6)$ & $1.8(0.5)$ & $-.82(.77)$ & $2.6(0.6)$ & $2.7(0.5)$ & $.11(.79)$ & .000 \\
\hline $\begin{array}{l}\text { Punishment for } \\
\text { Mistakes }\end{array}$ & $2.2(0.6)$ & $1.8(0.5)$ & $-.38(.72)$ & $2.5(0.6)$ & $2.4(0.6)$ & $-.13(.83)$ & .169 \\
\hline Unequal Recognition & $3.2(0.8)$ & $1.7(0.6)$ & $-1.4(1.1)$ & $2.7(0.9)$ & $3.0(0.7)$ & $.23(1.1)$ & .000 \\
\hline $\begin{array}{l}\text { Intra-Team Member } \\
\text { Rivalry }\end{array}$ & $2.3(0.7)$ & $2.0(0.8)$ & $-.24(1.1)$ & $2.4(0.7)$ & $2.7(0.8)$ & $.32(1.2)$ & 0.22 \\
\hline
\end{tabular}

Note. $\mathrm{P}$ values calculated with the Mann-Whitney $\mathrm{U}$ test in post-test/pre-test evolution between the experimental and control group; $\mathrm{SD}=$ Standard Deviation. 
From the data obtained it can be seen that the evolution of the Motivational Climate, as a global variable, does not differ significantly when comparing experimental and control groups. Nevertheless, focusing on the two scales of the test (Task-involvement and Ego-involvement) there is a significant difference in their progression. Besides, several of their subscales present statistically significant differences. This is the case with Effort/Improvement and Important Role within the Task-involvement scale, and Unequal Recognition within the Ego-involvement one. The rest of the subscales follow similar patterns although the comparison of their evolution between groups is not statistically significant.

\section{Discussion}

The present study found significant differences regarding the evolution of both Task-involvement and Ego-involvement scales. Previous research has dealt with students' opinions on the TGfU model and emphasized positive acceptance, improvement in tactical thinking and participation, as well as improvements in motivation, fun, satisfaction, and competition in sports games (Chen \& Light, 2006; Fry, Tan, McNeill, \& Wright, 2010; Griffin, Oslin, \& Mitchell, 1995; Jones, Marshall, \& Peters, 2010; Light, 2003; Sánchez-Gómez, Devís-Devís, \& Navarro-Adelantado, 2011; Úbeda-Colomer, Monforte, \& Devís-Devís, 2017). Next, the results obtained are discussed with regards to the established research objective and hypotheses. In relation to hypothesis 1 , it was proposed that the motivational climate would be altered after the implementation of the handball unit as a result of an increase in Task-involvement and a decrease in Ego-involvement. The findings confirm this hypothesis since significant differences have been found in these scales. For its part, Task-involvement showed a significant evolution, whereas Ego-involvement followed the same pattern in the opposite way. These results indicate that the hybrid model used contributed to the augmentation of Task-involvement and reduction of Ego-involvement. Just like Morgan, Kingston, and Sproule's study (2005), the present research reported that the game-based class discussed game understanding, teamwork, enjoyment, and involvement, which are all task-involved goals; in contrast, the skill-focused class only discussed the value of skill learning and evaluation of performance based on successful game skill execution, linked with Ego-involved goals. Therefore, game-focused teacher strategies appear to promote a mastery-oriented climate that increases students' motivation and reduces individual behaviours.

Other subscales, included within the aforementioned two, progressed similarly to these when comparing statistically the evolution of both groups. On the one hand, the evolution of the Task-involvement subscales such as Effort/Improvement and Important Role was statistically significant, which may be caused by individual responsibility originated by means of a new methodology due to its intra-group roles (Vazou, Ntoumanis, \& Duda, 2005). On the other hand, the Ego-involvement subscale Unequal Recognition displayed significant differences between groups. It decreased 
in the experimental group but increased in the control one. These results coincide with the work of Gray, Sproule, and Morgan (2009), who compared the effects of a methodological approach based on games and another based on the development of basketball skills. In their case, motivational climate increased. In our case, the findings show a decrease in Ego-involvement, which is certain to achieve greater motivation related to students' self-determination.

This fact is in agreement with the findings of González-Cutre et al. (2011), who manipulated the target areas across several motivational variables. Their study displays an increase in Task-involvement perception within the experimental group and a decrease in Ego-involvement. Moreover, Báguena, Sevil, Julián, Murillo, and García (2014) highlight a greater perception of Task-involvement among those students who had implemented a volleyball unit through an approach related to the TGfU model and specific strategies of target areas. Their findings are in accordance with those presented in this paper, since both cases recorded an increase in Task-involvement, but no decrease in Ego-involvement. Building our thesis on the qualitative analysis developed by Vazou et al. (2005), this leads us to consider that the aspects related to cooperative learning, including the hybrid model implemented in this paper, are those that entail a decrease in Ego-involvement.

With respect to hypothesis 2 , it was suggested that the evolution of the Motivational Climate would differ due to the change experienced by those students who implemented the handball unit through the hybrid model of learning. Based on the results obtained, we cannot confirm this hypothesis. The progression of the Motivational Climate variable was not statistically different when comparing experimental and control groups. At first glance, this was unexpected since Motivational Climate is intimately linked with the hybrid model and, therefore, the group that used this approach should have demonstrated a higher progression than the control group. Nevertheless, as Duda (2005) asserts, this result may be explained due to the interference that might have caused the dispositional orientation of the strategies perception and other dimensions related to a particular motivational climate. In fact, if we compare separately the evolution of the two main scales of the motivational climate, there is a significant progression within Task-involvement in favour of the experimental group, whereas Ego-involvement shows the opposite pattern. Particularly, significant differences appear in the evolution of many subscales such as Effort/Improvement, Important Role, and Unequal Recognition, which is in accordance with other relevant studies such as those conducted by Ames (1992), Gray et al. (2009), and Treasure (1993).

These results are consistent with those obtained by Morgan et al. (2005), who analysed the effects of four teaching styles on Motivational Climate and students' behaviour, finding that reciprocal style and guided discovery style contribute to an increase in Task-involvement and decrease in Ego-involvement, with greater relevance than command and practise styles. This is not surprising since reciprocal and guided discovery styles are in line with the method used in the hybrid model, whereas command and practise styles fit with the traditional approach to sports teaching. 


\section{Conclusions}

The following conclusions can be drawn from our research.

Hypothesis 1 has been accepted since significant differences have been found in the two scales of the questionnaire regarding the progression of both groups. Their evolution was compared, and significant differences between the Task-involvement and Ego-involvement scales were obtained. The former increased in the experimental group and decreased in the control group, while the opposite pattern was displayed in the latter.

Hypothesis 2 has not been accepted because there have been no significant differences regarding the progression of Motivational Climate when comparing experimental and control groups. The results did not show a significant improvement in the evolution of the global variable, perhaps due to the fact that the two scales that form it (Task-involvement and Ego-involvement) counteract each other. However, if we regard their evolution separately, there are significant differences that indicate the effect of the hybrid model.

Focusing on the main objective established, our findings suggest that the implementation of the handball unit based on the hybrid model (cooperative learning and the TGfU) of teaching sports was successful in terms of the Motivational Climate. On the contrary, the teaching unit based on the traditional approach did not show this positive impact.

Finally, the findings in this paper are subject to at least two limitations. Firstly, the short period of intervention which could have limited the effect produced on the students' Motivational Climate. Secondly, the number of participants was relatively small. However, these are drawbacks often linked to research in the field of educational innovation practices.

\section{References}

American College of Sport Medicine (ACSM). (2014). Guidelines for Exercise Testing and Prescription (9th ed.). Philadelphia: Lippincott.

Ames, C. (1992). Classrooms: Goals, structures, and student motivation. Journal of Educational Psychology, 84(3), 261-271. https://doi.org/10.1037/0022-0663.84.3.261

American Psychological Association. (2010). Manual de Publicaciones de la APA. Mexico City: Editorial El Manual Moderno.

Antón, J. L. (1990). Balonmano: fundamentos y etapas de aprendizaje. Madrid: Gymnos.

Báguena, J. I., Sevil, J., Julián, J. A., Murillo, B., \& García, L. (2014). El aprendizaje del voleibol basado en el juego en Educación Física y su efecto sobre variables motivacionales situacionales. Ágora para la Educación Física y el deporte, 16(3), 255-270. 
Balakrishnan, M., Shabeshan, R., \& Salleh, M. (2011). Effect of Teaching Games for Understanding. World Academy of Science, Engineering and Technology, 77, 961-963.

Barrett, T. (2005). Effects of cooperative learning on the performance of sixth-grade physical education students. Journal of Teaching in Physical Education, 24, 88-102. https://doi. org/10.1123/jtpe.24.1.88

Bunker, D., \& Thorpe, R. (1982). A model for the teaching of games in secondary schools. Bulletin of Physical Education, 18(1), 5-8.

Casey, A., \& Dyson, B. (2009). The implementation of models-based practice in physical education through action research. European Physical Education Review, 15(2), 175-199. https://doi.org/10.1177/1356336X09345222

Casey, A., Dyson, B., \& Campbell, A. (2009). Action research in physical education: Focusing beyond myself through cooperative learning. Educational Action Research, 17(3), 407-423. https://doi.org/10.1080/09650790903093508

Chen, S., \& Light, R. (2006). 'I thought I'd hate cricket but I love it!': Year six students' responses to Games Sense pedagogy. Change: Transformations in Education, 9(1), 49-58.

Duda, J. L. (2005). Motivation in Sport: The Relevance of Competence and Achievement Goals. In A. J. Elliot, \& C. S. Dweck (Eds.), Handbook of Competence and Motivation (pp. 273-308). New York: Guilford Publications.

Dyson, B. (2002). The implementation of cooperative learning in an elementary physical education program. Journal of Teaching in Physical Education, 22, 69-85. https://doi. org/10.1123/jtpe.22.1.69

Dyson, B. (2010). Un modelo híbrido de instrucción en Educación Física: integrando los modelos del aprendizaje cooperativo y de los juegos tácticos. In C. Velázquez (Ed.), Aprendizaje cooperativo en Educación Física: fundamentos y aplicaciones prácticas (pp. 99118). Barcelona: INDE Publicaciones.

Fernández-Río, J. (2009). El modelo de Aprendizaje Cooperativo. Conexiones con la Enseñanza Comprensiva. In A. Méndez-Giménez (Ed.), Modelos actuales de iniciación deportiva escolar: Unidades didácticas sobre deportes de invasión (pp. 75-99). Sevilla: Wanceulen.

Fernández-Río, J., \& Méndez-Giménez, A. (2016). El Aprendizaje Cooperativo: Modelo Pedagógico para Educación Física. Retos. Nuevas Tendencias en Educación Física, Deporte y Recreación, 29, 201-206.

Fry, J. M., Tan, C. W. K., McNeill, M., \& Wright, S. (2010). Children's perspectives on conceptual games teaching: A value-adding experience. Physical Education and Sport Pedagogy, 15(2), 139-158. https://doi.org/10.1080/17408980902813927

González, C., Cecchini, J. A., Fernández-Río, J., \& Méndez, A. (2008). Posibilidades del modelo comprensivo del aprendizaje cooperativo para la enseñanza deportiva en el contexto educativo. Aula Abierta, 36(1,2), 27-38.

González-Cutre, D., Sicilia, Á., \& Moreno, J. A. (2008). Modelo cognitivo-social de la motivación de logro en Educación Física. Psicothema, 20(4), 642-651.

González-Cutre, D., Sicilia, Á., \& Moreno, J. A. (2011). Un estudio cuasi-experimental de los efectos del clima motivador tarea en las clases de Educación Física. Revista de educación, $356,677-700$. 
Gray, S., Sproule, J., \& Morgan, K. (2009). Teaching team invasion games and motivational climate. European Physical Education Review, 15(1), 65-89. https://doi. org/10.1177/1356336X09105212

Griffin, L., Oslin, J. L., \& Mitchell, S. A. (1995). An analysis of two instructional approaches to teaching net games. Research Quarterly for Exercise and Sport, 66, 65-66.

Griffin, L. L., \& Patton, K. (2005). Two decades of teaching games for understanding: Looking at the past, present, and future. In L. Griffin, \& J. Butler (Eds.), Teaching Games for Understanding: Theory, Research, and Practice (pp. 1-17). Champaign, Illinois: Human Kinetics.

Griffin, L., Brooker, R., \& Patton, K. (2006). Working towards legitimacy: Two decades of teaching games for understanding. Physical Education and Sport Pedagogy, 10(3), 213-223. https://doi.org/10.1080/17408980500340703

Gröben, B. (2005). Wirkungen des Kooperativen Lernens im Spiegel der Unterrichtsforschung. Sportpädagogik, 29(6), 48-52.

Johnson, D. W., Johnson, R. T., \& Holubec, E. J. (1999). El aprendizaje cooperativo en el aula. Buenos Aires: Paidós.

Johnson, J. G., \& Raab, M. (2003). Take the first: Option-generation and resulting choices. Organizational Behaviour and Human Decision Processes, 91, 215-229. https://doi. org/10.1016/S0749-5978(03)00027-X

Jones, R. J. A., Marshall, S., \& Peters, D. M. (2010). Can we play a game now? The intrinsic value of TGfU. European Journal of Physical and Health Education, 4(2), 57-63.

Kirk, D., Macdonald, D., \& O’Sullivan, M. (2006). Handbook of Physical Education. London: SAGE Publications.

Light, R. (2003). The joy of learning: Emotion and leaning in games through TGfU. Journal of Physical Education New Zealand, 36(1), 93-108.

López, V. M., Monjas, R., \& Pérez, D. (2003). Buscando alternativas a la forma de entender y practicar la educación física escolar. Barcelona: Inde.

Memmert, D., Simons, D. J., \& Grimme, T. (2009). The relationship between visual attention and expertise in sports. Psychology of Sport and Exercise, 10, 146-151. https://doi. org/10.1016/j.psychsport.2008.06.002

Méndez-Giménez, A. (2010). El Aprendizaje Cooperativo, la Enseñanza Comprensiva y el Modelo de Educación Deportiva: revisión de analogías, características e hibridaciones. In A. Fraile, \& Velázquez, C. (Eds.), VII Congreso Internacional de Actividades Físicas Cooperativas, Valladolid: 30 de junio al 3 de julio de 2010 (pp. 1-29). Valladolid: Universidad de Valladolid.

Mertens, D. M. (2010). Research and Evaluation in Education and Psychology: Integrating Diversity with Quantitative, Qualitative, and Mixed Methods (3rd ed.). Thousand Oaks, CA: SAGE.

Metzler, M. W. (2011). Instructional Models for Physical Education. Scottsdale, Arizona: Holcomb Hathway.

Moreno, J. A., Cervelló, E., Huéscar, E., Belando, N., \& Rodríguez, J. J. (2013). Motivational Profiles in Physical Education and Their Relation to the Theory of Planned Behaviour. Journal of Sports Science \& Medicine, 12(3), 551-558. 
Morgan, K., Kingston, K., \& Sproule, J. (2005). Effects of different teaching styles on the teacher behaviours that influence motivational climate and pupils' motivation in physical education. European Physical Education Review, 11(3), 257-285. https://doi. org/10.1177/1356336X05056651

Müller, M., Gert-Stein, H., Konzag, I., \& Konngaz, B. (1996). Balonmano: entrenarse jugando. Barcelona: Paidotribo.

Newton, M. L., Duda, J. L., \&Yin, Z. (2000). Examination of the psychometric properties of the Perceived Motivational Climate in Sport Questionnaire-2 in a sample of female athletes. Journal of Sport Science, 18(4), 275-290. https://doi.org/10.1080/026404100365018

O'Leary, N. (2015). Learning informally to use the 'full version' of teaching games for understanding. European Physical Education Review, 22(1), 3-22. https://doi. org/10.1177/1356336X15586177

Peiró, C. (1999). La teoría de las perspectivas de meta y la Educación Física: un estudio sobre los climas motivacionales. Revista de psicología social aplicada, 9(1), 25-44.

Prieto, J. A., \& Nistal, P. (2009). Influencia del aprendizaje cooperativo en Educación Física. Revista Iberoamericana de Educación, 49(4), 1-8.

Raab, M., \& Johnson, J. G. (2007). Expertise-based differences in search and optiongeneration strategies. Journal of Experimental Psychology, 13(3), 158-170. https://doi. org/10.1037/1076-898X.13.3.158

Raab, M., \& Laborde, S. (2011). When to blink and when to think: Preference for intuitive decisions results in faster and better tactical choices. Research Quarterly for Exercise and Sport, 82, 89-98. https://doi.org/10.1080/02701367.2011.10599725

Renshaw, I., Araújo, D., Button, C., Chow, J. Y., Davids, K., \& Brendan, M. (2016). Why the Constraints-Led Approach is Not Teaching Games for Understanding: A Clarification. Physical Education and Sport Pedagogy, 21(5), 459-480. https://doi.org/10.1080/174089 $\underline{89.2015 .1095870}$

Ryan, R. M., \& Deci, E. L. (2007). Active human nature: Self-determination theory and the promotion and maintenance of sport, exercise, and health. In M. S. Hagger, \& N. L. D. Chatzisarantis (Eds.), Intrinsic Motivation and Self-Determination in Exercise and Sport (pp. 1-19). Champaign, IL: Human Kinetics.

Sánchez-Gómez, R., Devís-Devís, J., \& Navarro-Adelantado, V. (2011). Los juegos y las modificaciones según el alumnado en el modelo comprensivo. Tándem: Didáctica de la Educación Física, 37, 20-30.

Swinney, G. (2004). Teaching Games for Understanding/Games Sense. What's about All It? Hitting the Same. The Official Newsletter of the England and Wales Cricket Board Coach Education Department, 14, 10-11.

Thorpe, R., Bunker, D., \& Almond, L. (1984). A change in focus for the teaching of games. In M. Pieron, \& G. Graham (Eds.), Sport Pedagogy. Olympic Scientific Congress Proceedings, Vol. 6 (pp. 163-169). Champaign, IL: Human Kinetics.

Tinning, R. (1996). Discursos que orientan el campo del movimiento humano y el problema de la formación del profesorado. Revista de Educación, 311, 123-134.

Tinning, R. (2006). Theoretical orientations in physical education teacher education. In D. Kirk, D. MacDonald, \& M. O'Sullivan (Eds.), The Handbook of Physical Education (pp. 369-385). London: SAGE. https://doi.org/10.4135/9781848608009.n21 
Treasure, D. C. (1993). A Social-Cognitive Approach to Understanding Children's Achievement Behaviour, Cognitions, and Affect in Competitive Sport. (Unpublished doctoral dissertation, University of Illinois). Illinois: University of Illinois at Urbana-Champaign.

Úbeda-Colomer, J., Monforte, J., \& Devís-Devís, J. (2017). Percepción del alumnado sobre una unidad didáctica de enseñanza comprensiva de los juegos deportivos de invasión en educación física. Retos, 31, 275-281.

Vazou, S., Ntoumanis, N., \& Duda, J. (2005). Peer motivational climate in youth sport: a qualitative inquiry. Psychology of Sport and Exercise, 6(5), 497-516. https://doi. org/10.1016/j.psychsport.2004.03.005

Velázquez, C. (2015). Aprendizaje cooperativo en Educación Física: estado de la cuestión y propuesta de intervención. Retos, 28, 234-239.

Wagner, H., Finkenzeller, T., Würth, S., \& von Duvillard, S. P. (2014). Individual and Team Performance in Team-Handball: A Review. Journal of Sports Science \& Medicine, 13(4), 808-816.

Wang, L., \& Ha, A. (2013). Three groups of teachers' views, learning experiences, and understandings of teaching games for understanding. Physical Education and Sport Pedagogy, 18(3), 336-350. https://doi.org/10.1080/17408989.2012.666789

Werner, P., Thorpe, R., \& Bunker, D. (1996). Teaching Games for Understanding: Evolution of a Model. Journal of Physical Education, Recreation \& Dance, 67(1), 28-33. https://doi.or $\mathrm{g} / 10.1080 / 07303084.1996 .10607176$

\section{Óscar Chiva-Bartoll}

Jaume I University, Department of Education

Av. Sos Baynat s/n, Castelló 12071, Spain

ochiva@uji.es

\section{Celina Salvador García}

Jaume I University, Department of Education

Av. Sos Baynat s/n, Castelló 12071, Spain

salvadoc@uji.es

\section{Pedro Jesús Ruiz-Montero}

University of Granada,

Department of Physical Education and Sport

C/Santander, 1, 52071 Melilla 52071, Spain

pedrorumo@ugr.es 